\title{
Reviewer Acknowledgements for English Linguistics Research, Vol. 8, No. 4
}

\begin{abstract}
English Linguistics Research (ELR) would like to acknowledge the following reviewers for their assistance with peer review of manuscripts for this issue. Many authors, regardless of whether ELR publishes their work, appreciate the helpful feedback provided by the reviewers. Their comments and suggestions were of great help to the authors in improving the quality of their papers. Each of the reviewers listed below returned at least one review for this issue.
\end{abstract}

\section{Reviewers for Volume 8, Number 4}

Alina Andreea Dragoescu Urlica, University of Life Sciences, Romania

Girolamo Tessuto, University of Naples, Italy

Hülya Tuncer, Çukurova University, Turkey

Kate Short-Meyerson, University of Wisconsin Oshkosh, USA

Nassier Al-Zubaidi, University of Baghdad, Iraq

Omer Elsheikh Hago Elmahdi, Taibah University, Saudi Arabia

Sawsan M.A. Ahmed, Taif University, Saudi Arabia

Wagdi Bin-Hady, Hadhramout University, Yemen

Win Whelan, St. Bonaventure University, USA

Zeineb Ayachi Ben Abdallah, Higher Institute of Human Sciences Jendouba, Tunisia

Best Regards,

Camille $\mathrm{Su}$

Editorial Assistant, English Linguistics Research

Sciedu Press

$* * * * * * * * * * * * * * * * * * * * * * * * * * * * * * * * * * * * * *$

Add: 9140 Leslie St. Suite 110, Beaver Creek, Ontario, L4B 0A9, Canada

Tel: 1-416-479-0028 ext. 210

Fax: 1-416-642-8548

E-mail1: elr@sciedupress.com

E-mail2: elr@sciedupress.org

Website: http://elr.sciedupress.com 